\title{
Historical perspectives of The American Association for Thoracic Surgery: Floyd D. Loop (1936-2015)
}

\author{
John V. Conte, MD
}

Floyd D. Loop, the 78th president of The American Association for Thoracic Surgery (AATS), was born in Lafayette, Indiana, on December 17, 1936. "Fred," as he was known to his friends, listed his most influential mentors as a youth as his parents. His mother was a professor at the University of Illinois and at Purdue University and introduced him to the arts. His father was a country doctor who did everything from treating the flu to removing appendices and delivering babies. Loop often accompanied his father to see patients on their farms, carrying his black bag, and said, "I knew right away I wanted to be a doctor." 1 Loop's childhood in the Midwest was spent outdoors when he was not in school. He had many outside jobs and developed an interest in horticulture at a young age that continued throughout his life. At the age of 11, he had a paper route, which he continued through his college years. He also worked on farms, on the railroad, and in other labor intensive industries throughout the city. Loop completed his undergraduate education at Purdue University and medical school at George Washington University (GW), his father's alma mater. His father had graduated number one in his class, and Loop himself was in the Alpha Omega Alpha Honor Medical Society at GW, where he graduated in 1962.

After medical school, Loop joined the Berry plan (US Air Force), as did many Vietnam-era medical school graduates. He did his surgical internship at GW under Dr Brian Blades (27th AATS president), who became a pivotal figure in his career. Blades arranged for Loop to serve his time at Andrews Air Force Base, after which he returned to GW to complete his surgical residency in 1968. When Loop told Blades he wanted to be a cardiothoracic surgeon and go to England to train, Blades was pleased with his career choice but had other plans for his training. Blades told Loop that he should go to Cleveland to train under one of his former residents, Dr Donald Effler, and then return to GW to practice cardiac surgery once he had learned "the new kind of surgery that is taking place there."2 Loop recounted during an interview in preparation for

\footnotetext{
From the Division of Cardiac Surgery, Department of Surgery, Johns Hopkins University School of Medicine, Baltimore, Md.

Disclosures: Author has nothing to disclose with regard to commercial support.

Received for publication Aug 27, 2015; accepted for publication Sept 22, 2015; available ahead of print Oct 23, 2015.

Address for reprints: John V. Conte, MD, Division of Cardiac Surgery, Department of Surgery, Johns Hopkins Medical Institutions, $600 \mathrm{~N}$ Wolfe St, Blalock 618,

Baltimore, MD 21287 (E-mail: jconte@jhmi.edu).

J Thorac Cardiovasc Surg 2016;151:607-9

$0022-5223 / \$ 36.00$

Copyright (c) 2016 by The American Association for Thoracic Surgery http://dx.doi.org/10.1016/j.jtcvs.2015.09.088
}

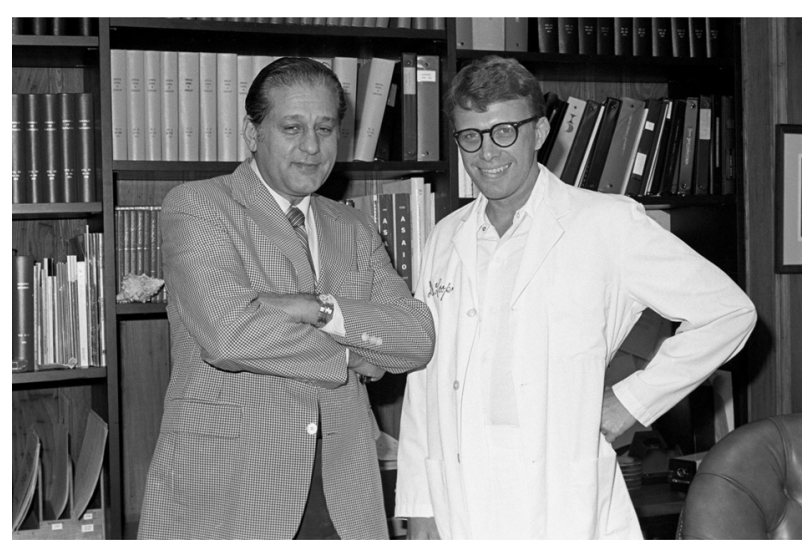

FIGURE 1. Drs Rene Favalaro and Floyd Loop, 2 of the early innovators in coronary artery bypass grafting surgery. (Courtesy of John Bowen, Cleveland Clinic Foundation Archives.)

the AATS Centennial, "When you're young and very impressionable and you have great respect for a mentor like Brian Blades, you do exactly as you are told. I went to Cleveland.",2

Loop trained in cardiac surgery with Effler and Dr Rene Favalaro and learned coronary angiography from Dr Mason Sones. He completed his training in 1970; however, he never left Cleveland and spent his entire career at the Cleveland Clinic. It was the beginning of direct coronary artery surgery, and he was at ground zero. Loop and Favalaro (shown together in Figure 1) were 2 of the most important individuals in making coronary artery surgery the mainstay of treatment for atherosclerotic coronary artery disease.

After 5 years on staff, Loop became its chair, and he served in that role from 1975 to 1999 . Under his watch, the department doubled its volume of cases and assembled a team of expert surgeons who would go on to lead their specialty and set the pace for years to come. The result was a consolidated reputation as one of the world's great cardiac surgery centers. He and his Cleveland Clinic Foundation (CCF) colleagues were responsible for many developments in cardiac surgery, including the use of arterial conduits in coronary artery surgery, innovations in valve repair, and pioneering technical improvements for cardiac reoperations, and the Cleveland Clinic surgeons were among the first to use public outcomes reporting as a mechanism for quality improvement. Loop performed more than 12,000 operations during his career, had more than 360 publications, and served on numerous health care publication editorial boards. Loop was instrumental 


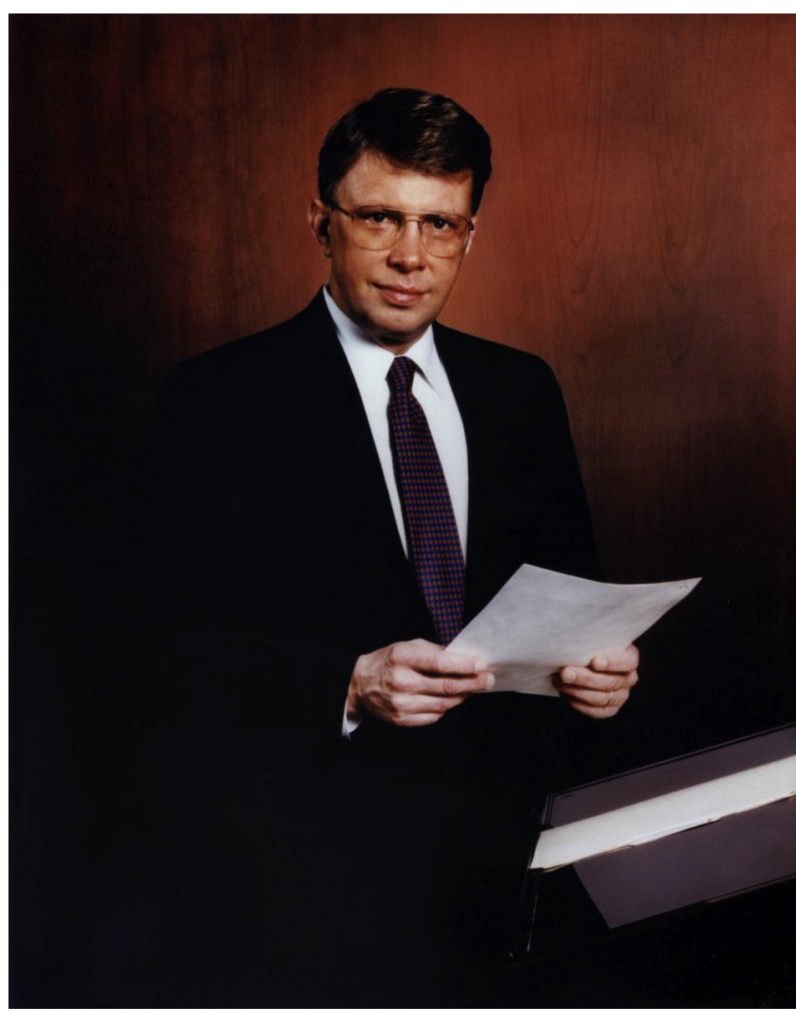

FIGURE 2. Official picture of Floyd D. Loop, MD, as chief executive officer of Cleveland Clinic in 1989. (Courtesy of John Bowen, Cleveland Clinic Foundation Archives.)

in establishing the world's first computerized registry of cardiac surgery outcomes, which culminated in the landmark 1986 New England Journal of Medicine article establishing the superiority of using the internal thoracic artery in coronary artery bypass grafting procedures.

Loop was the chair at the Residency Review Committee for Thoracic Surgery, served as a Director of American Board of Thoracic Surgery, and served in leadership roles with the American College of Surgeons and the American Heart Association and as a member of the Medicare Payment Advisory Commission. Loop received numerous awards, including the American Heart Association Citation for International Service, the American College of Cardiology Cummings Humanitarian Award in 1975, the American Heart Association Citation for International Service in 1980, and in 1982 the Order of Merit, Brazil's highest civilian award given. He has received Honorary Doctor of Science degrees from Cleveland State University, St Louis University, and his undergraduate alma mater, Purdue University. Loop was AATS president in 1997 and 1998. His presidential address, "The First Living and the Last Dying," was delivered in Boston on May 4, 1998.

In 1989, he was selected as the chief executive officer (CEO) and chair of the Board of Governors of the CCF. He served in this role from 1989 to 2004 while still practicing cardiac surgery until 1999 (Figure 2). As CEO, he is credited with guiding the CCF through an era of unprecedented growth and expansion. Under his leadership, the CCF became an international organization and was named one of America's best hospitals in U.S. News \& World Report's newly instituted "best hospitals" survey. He led the Clinic through more than a decade of change, from an institution known mostly for heart care to a fully integrated medical delivery system of acquired hospitals, newly constructed outpatient clinics, and an expansion into Florida and overseas. He also oversaw the building of research, eye, cancer, and heart institutes, as well as the inauguration of the Cleveland Clinic Lerner College of Medicine of Case Western Reserve University. During Loop's tenure as CEO, growth pushed Cleveland Clinic revenues to \$3.6 billion in 2004 from \$645 million in 1989.

Loop was the proud father of 5 children. He had daughters Alison Potter and Kendall Mathea, along with his son Frederick Addison, with his first wife Judith. His second wife, Dr Bernadine Healy (Figure 3), was herself a renowned cardiologist and head of the American Heart Association (1988-1989), the National Institutes of Health (1991-1993), and the American Red Cross (1999-2002). Together they had 1 daughter, Marie McGrath Loop, and their blended family included step-daughter Bartlett from Healey's first marriage. Loop was a man of many diverse interests. He was a horticulturalist who raised vegetables, berries, and eventually an apple orchard. His success with these activities led to his building a greenhouse, where he raised orchids and exotic flowers to help him get through the cold Cleveland winters. His green thumb was legendary, and his closest friends can tell stories of Loop nursing sick orchids back to health in his "orchid intensive care unit." He was an avid reader of American history, and his fondness of history is reflected in the names of his most prized possessions, his dogs Lewis and Clark.

Loop retired as CEO in 2004. He continued to advise and mentor, serving on various private and public corporate

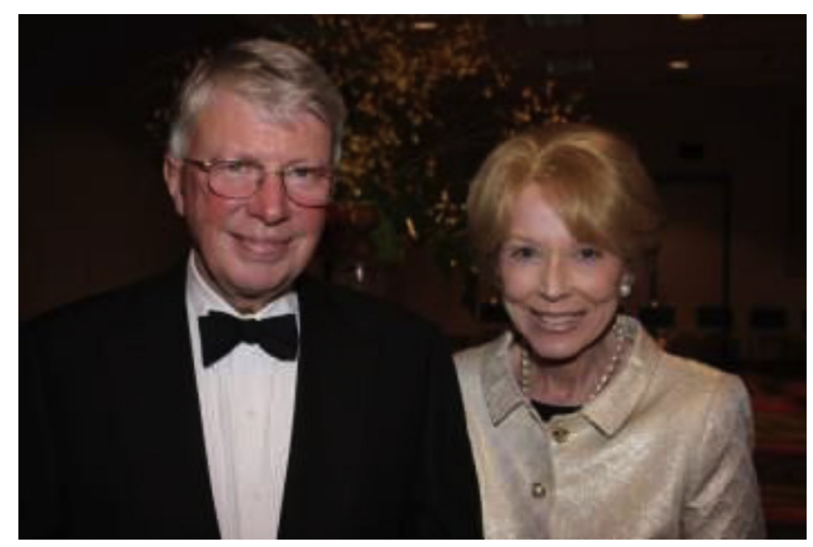

FIGURE 3. Drs Floyd Loop and Bernadine Healy. 
boards. He became an author and authority on leadership. His book Leadership and Medicine discussed the role of physician leaders in modern health care. Two particularly poignant pieces of advice he offered in his book are "Never forget the importance of a satisfied patient," and "Learn the fine art of partnering with community physicians." 3

Loop passed away June 11, 2015, surrounded by family. "As a cardiac surgeon and physician leader, his contributions to medicine and to the growth of Cleveland Clinic will be remembered forever," says Dr Delos Cosgrove, himself a cardiac surgeon who succeeded him as CEO of CCF. "He will be remembered by all of us who knew him as the epitome of a renaissance man and for his moral commitment to loyalty and truth in all aspects of dealing with patients and his colleagues," adds Dr Lars G. Svensson, chair of the Miller Family Heart and Vascular Institute. ${ }^{4}$
At the time of his retirement as CEO, Loop summed up his career at Cleveland Clinic in this way: "We're all here to do the best possible job, and that's what I tried to do. I think I leave it better than I found it." ${ }^{4}$ Loop not only had that impact on the Cleveland Clinic, he also left the field of cardiothoracic surgery better than when he found it.

\section{References}

1. Stoney W. Interview with Dr. Floyd Loop. Chicago: CTSNet; May 5, 2003. Available at: http://www.ctsnet.org/article/interview-dr-floyd-loop. Accessed July 17, 2015.

2. Moon M. AATS past president interview. January 12, 2011. AATS Centennial [pending publication]

3. Loop FD. Leadership and medicine. Gulf Breeze, FL: Fire Starter Publishing: 2009.

4. Remembering pioneering heart surgeon and former Cleveland Clinic CEO Floyd D. Loop, MD (1936-2015). Consult QD—heart \& vascular website [Internet]. Cleveland: Cleveland Clinic; 2015. Available at: http://consultqd.cleveland clinic.org/2015/06/page/3/. Accessed June 19, 2015. 